Geliş Tarihi:

10.09.2020

Kabul Tarihi:

24.10.2021

Yayımlanma Tarihi:

20.12.2021
Kaynakça Gösterimi: Fettahoğlu, S., \& Sayan, Ö. (2021). Attitudes of individuals about using cryptocurrencies: evidence from Turkey. Istanbul Ticaret Üniversitesi Sosyal Bilimler Dergisi, 20(42), 1122-1146. doi:10.46928/iticusbe. 793380

\title{
ATTITUDES OF INDIVIDUALS ABOUT USING CRYPTOCURRENCIES: EVIDENCE FROM TURKEY
}

Research

Sibel Fettahoğlu

Sorumlu Yazar (Correspondence)

Kocaeli University

stopdemir@kocaeli.edu.tr

Özge Sayan

Kocaeli University

ozge.sayan@gazi.edu.tr

Sibel Fettahoğlu, Kocaeli Üniversitesi, İIBF-İşletme Bölümü Muhasebe ve Finansman A.B.D. öğretim üyesidir. Finans alanında doçenttir. İşletme finansmanı başta olmak üzere finans alanında ders vermekte ve bu alanlarda araştırmalar yayınlamaktadır.

Özge Sayan, Gazi Üniversitesi İIBF İşletme Bölümü mezunudur. Kocaeli Üniversitesi Muhasebe ve Finansman A.B.D. Tezli Yüksek Lisans Programında eğitimine devam etmektedir. Aynı zamanda sermaye piyasalarında geniş yetkili bir aracı kurumda çalışmaktadır. 


\title{
ATTITUDES OF INDIVIDUALS ABOUT USING CRYPTOCURRENCIES: EVIDENCE FROM TURKEY
}

\author{
Sibel Fettahoğlu \\ stopdemir@kocaeli.edu.tr \\ Özge Sayan \\ ozge.sayan@gazi.edu.tr
}

\begin{abstract}
Purpose: The study aimed to determine why Turkish participants are voluntary or hesitant to use cryptocurrencies and to assess which factors affected cryptocurrencies usage.

Method: Technology acceptance model (TAM) was used in the study to analyze Turkish individuals' cryptocurrency usage behavior. Structural equation (regression) modeling (SEM) was used to test the research model. AMOS and SPSS programs were used for analysis.

Findings: The study model showed that cryptocurrency usage was exposed to the most effect by perceived benefit. Contrary to expectations, perceived risk did not make any significant effect on usage behavior. A causality relation between perceived benefit and decentralization factor was found more than other benefit sub-factors. Perceived ease of use had no positive direct relation with usage behavior in the study. Perceived ease of use had a positive relation with perceived benefit in the study.
\end{abstract}

Originality: There has been no research about attitudes about cryptocurrencies in Turkey.

Keywords: Cryptocurrency, Bitcoin, Perceived Risk, Perceived Benefit, Perceived Ease of Use, Behavior.

JEL Classification: G23, F65, G4 


\section{BİREYLERİN KRİPTO PARA KULLANIMINA İLIŞKİN TUTUMLARI: TÜRKIYYE'DEN BIR UYGULAMA}

\section{ÖZET}

Amaç: Çalışmada, Türk katılımcıların kripto paraları kullanmakta neden istekli olduklarını veya neden tereddüt ettiklerini belirlemek ve kripto paraların kullanımını etkileyen faktörleri değerlendirmek amaçlanmaktadır.

Yöntem: Çalışmada Türk bireylerin kripto para kullanımına dair tutumlarını analiz etmek için teknoloji kabul modeli (TAM) kullanılmıştır. Araştırma modelini test etmek için yapısal denklem (regresyon) modellemesi (SEM) kullanılmıştır. Analiz için AMOS ve SPSS programlarından yararlanılmıştır.

Bulgular: Çalışma modeli, kripto para kullanımının en fazla algılanan faydadan etkilendiğini göstermiştir. Beklentilerin aksine, algılanan risk kullanım davranışı üzerinde önemli bir etki yaratmamıştır. Algılanan fayda ile merkezi olmayan yapılanma faktörü arasında nedensellik ilişkisi diğer fayda alt faktörlerinden daha fazla bulunmuştur. Algılanan kullanım kolaylığının kullanım davranışı ile çalışmada olumlu doğrudan bir ilişkisi yoktur. Algılanan kullanım kolaylı̆̆ının algılanan fayda ile çalışmada olumlu bir ilişkisi vardır.

Özgünlük: Türkiye’de kripto para tutumuna yönelik bir araştırmaya rastlanılmamıştır.

Anahtar Kelimeler: Kripto Para, Bitcoin, Algılanan Risk, Algılanan Fayda, Algılanan Kullanım Kolaylığı, Davranış.

JEL Sinıflandırması: G23, F65, G4 


\section{INTRODUCTION}

Today, the journey of money starting with gold travels by abstracting towards gold-based paper money, fiat money, digital and virtual (crypto) money. The digitalization process that began with payment and transfer transactions in the electronic environment with point of sale (POS) devices continued with systems such as DigiCash, First Virtual, PayPal, WebMoney, E-gold and Liberty Reserve. Bitcoin, the first cryptocurrency developed in 2009, came to life based on the know-how of these prior systems, and money gained a new dimension (Çarkacioğlu, 2016). Cryptocurrencies that are used for online payments with the help of digital signatures in the decentralized system were announced by Satoshi Nakamoto (2008). The European Banking Authority (EBA) (2014) named cryptocurrencies as virtual currencies and defined them as digital values that can be transferred, stored and traded electronically.

Today, virtual cryptocurrency's market value is nearly $\$ 225$ billion and virtual cryptocurrency types are almost 5,183 (Coinmarketcap, n.d.). Users of cryptocurrency can make money transfers, purchase cryptocurrency for hedging and arbitrage or use cryptocurrency as an investment instrument in the long term. They can use cryptocurrency for shopping (as stated in the EBA study) and that especially Bitcoin is essential in the e-cash flow system for countries and e-commerce sites. The EBA study also determined that participants had an increasing the great interest and aspire to use Bitcoin technology as well as an increasing safety, even if there was not any central authority. Corbet, Meegan, Larkin, Lucey, and Yarovaya (2018) indicated in their study that cryptocurrencies were new investment asset groups since they were interrelated with each other and had similar relations with other asset groups. Akyildirim, Corbet, Lucey, Sensoy, and Yarovaya (2020) stated in their study that when volatility increases in financial markets, investors' fear influences these new financial products.

Since crypto money markets, which constitute a new option in financial markets, are still in a systematic development and acceptance process, attitudes towards crypto money is a matter of curiosity. Considering the developments in the world and Turkey about cryptocurrencies, it is observed that their use and interest are widespread and growing. When national and international researchers examined them, a study about attitudes for using cryptocurrencies in Turkey couldn't be found. So, in this study, a survey was prepared for participants in Turkey. The aim of the study is to determine why Turkish participants are voluntary or hesitant to use cryptocurrencies and to assess which factors affected cryptocurrencies usage. The study has four parts. The first part includes importance and development of cryptocurrencies. The second part presents basic concepts about cryptocurrencies and their exchange mechanisms. In the third part, analysis and findings are shared. In the last part, conclusions about the study are stated. 


\section{THEORETICAL BACKGROUND AND HYPOTHESIS DEVELOPMENT}

In this part, theoretical background about cryptocurrencies and their exchange was tried to express. In here, some cryptocurrencies and exchange platforms were indicated with their advantagesdisadvantages on each other.

\section{Cryptocurrencies}

The European Central Bank (ECB) (2019) Crypto-Assets Task Force defined a crypto-asset as "a new type of asset recorded in digital form and make possible the use of cryptography that is not and does not represent a financial claim on, or liability of, any identifiable entity" (Bindseil, 2019; Bullmann, Klemm, \& Pinna, 2019). According to Oxford Dictionary (n.d.), “A cryptocurrency is a digital currency in which encryption techniques are used to control the production of units of currency and confirm the transfer of funds, operating separately of one single central unit". Cryptocurrency businesses often collect money through initial coin offerings (ICOs) (Lynn, Mooney, Rosati, \& Cummins, 2019; Schueffel, Groeneweg, \& Baldegger, 2019). Cryptocurrencies are based on blockchain technologies. They create money without central banks and simplify payments without financial institutions. The success of cryptocurrencies puts competitive pressure on financial institutions.

However, severe limitations have become obvious. Decentralized organization of markets without financial institutions can be very costly. Additionally, volatility of the value of crypto currencies is a significant barrier to their becoming an alternative to fiat money (WorldBank, 2018). The top 10 cryptocurrencies' market capitalization was showed in Table 1. In this study, cryptocurrencies and openended alternatives were listed to the survey participants to determine usage and awareness of cryptocurrency types.

Table 1. Top 10 Cryptocurrencies by Market Capitalization

\begin{tabular}{lll}
\hline Cryptocurrencies & Market Cap & Price \\
\hline \hline Bitcoin & $\$ 150.898 .488 .141$ & $\$ 8.389,64$ \\
Ethereum & $\$ 20.269 .922 .621$ & $\$ 187.51$ \\
XRP & $\$ 11.734 .966 .547$ & $\$ 0.271852$ \\
Tether & $\$ 4.173 .596 .564$ & $\$ 1.02$ \\
Bitcoin Cash & $\$ 4.108 .769 .984$ & $\$ 227.62$ \\
Litecoin & $\$ 3.601 .632 .750$ & $\$ 56.77$ \\
EOS & $\$ 2.933 .215 .749$ & $\$ 3.14$ \\
Binance Coin & $\$ 2.641 .212 .971$ & $\$ 16.98$ \\
Bitcoin SV & $\$ 1.555 .062 .642$ & $\$ 87.09$ \\
Stellar & $\$ 1.212 .659 .960$ & $\$ 0.060561$ \\
\hline
\end{tabular}

Reference: Coinmarketcap (n.d.)

An open-ended question was prepared for participants to determine their knowledge and usage of cryptocurrencies. In Figure 1, it shows the percentages about cryptocurrencies, which are known and used by participants in the survey. Ninety-seven (97) different cryptocurrencies were mentioned besides the most often stated ADA, BCH, BNB, BTC, EOS, ETH, HOT, LTC, MIOTA, TRX, XLM and XRP. 
As a result, it was determined that the participants were interested in cryptocurrencies and actively used them.

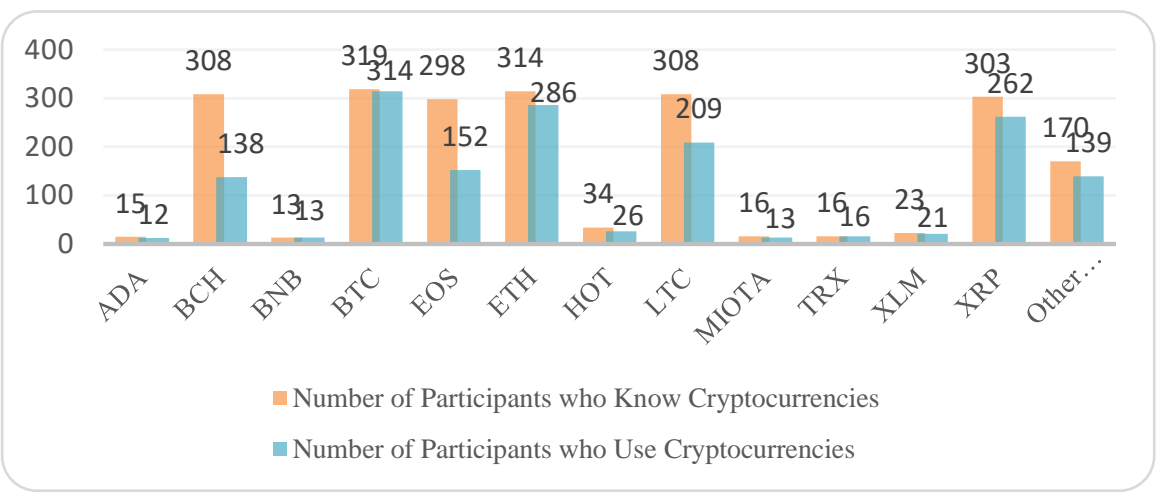

Figure 1. Types of Cryptocurrencies Which are Known and Used by Participants

Bitcoin, Bitcoin Cash, Ethereum, Ripple, Litecoin, EOS and Holochain's properties and their working mechanisms were presented as described below.

Bitcoin (BTC) was the first decentralized cryptocurrency that was created in 2008. The aim of Bitcoin was to enable online payments to be sent without a financial institution from one person to another. Bitcoin uses blockchain technology. A transaction in the network is saved in the blockchain and can be seen by everyone. In a blockchain, the proof of work algorithm is applied to confirm processes and making a new block. This work is called as mining and users are called as miners. So, Bitcoin protocol makes use of proof of work to prevent cyber-attacks (Tschorsch \& Scheuermann, 2016). Bitcoin can be considered as a reference indicator of cryptocurrency because all alternative cryptocurrency market prices are matched to the price of bitcoin (Ahamad, Nair, \& Varghese, 2013).

Bitcoin Cash (BCH) was formed from Bitcoin to increase the transaction speed and lighten system volume in 2017. In Bitcoin cash, the block size was upgraded for leading to faster corroboration times. If transaction sequence increases, the block's filling ratio will be increased. So, this situation causes transactions to accumulate. For example, a sent Bitcoin transaction couldn't have occurred because of a waiting list. If bitcoin is spent, the transaction cannot be reversed. Miners can add new blocks by overwriting the previous transactions. This situation caused high transaction fee payments to miners. So, miners prefer transactions that paid the most transaction fees. This mechanism is called as the replace by fee (RBF) mechanism. Bitcoin Cash doesn't use the RBF mechanism and can make self-destruction.

Ethereum (ETH) has its own custom programming language that allows people to write scripts. This system is called intelligent contracts. Ethereum is also called blockchain 2.0 and digital oil because of widening the classical blockchain frontiers with smart contracts and crowdsourcing. Bitcoin is programmed to record all transactions into a new block roughly every 10 minutes; Ethereum does this 
process in 15 seconds. Bitcoin's upper limit is 21 million pieces; Ethereum's upper limit is yearly 18 million pieces. The bitcoin mining system depends on the power of processors and system numbers; Ethereum uses the ASIC (application specific integrated circuits) system to establish equilibrium between producers (K1lınç, 2017).

Ripple (XRP) is a payment settling and currency exchange that was improved for banks and payment networks. Ripple cannot be used for shopping. Ripple aims to provide a peer-to-peer (P2P) system to transfer assets in minimum time at a lower price. It is an option for the SWIFT payment system. Ripple uses RippleNet as network for confirming servers (Narman, Uulu, \& Liu, 2018). So, there is no mining for Ripple, which is contrary from other altcoins. This is the most important differentiation between bitcoin and Ripple.

Bitcoin is distributed to a lot of wallet addresses, but Ripple is $60 \%$ owned by Ripple Labs. The mean transaction cost within Ripple is $\$ 0.0011$ and $\$ 3.50$ within Bitcoin. So, the transaction cost is significantly cheaper with Ripple. Ripple uses ECDSA and ED25519 algorithms as security algorithms and there is a high-security level according to these algorithms. Ripple is working with Akbank in Turkey (Karaslan, 2018).

Litecoin (LTC) is also a decentralized cryptocurrency; it is also called digital silver. The main difference between Bitcoin and litecoin is mining algorithms. Bitcoin creates blocks in the blockchain mechanism in 10 minutes, but litecoin completes the same process in 2.5 minutes. So litecoin's speed of transaction validation is 4 times faster. Bitcoin's upper limit is 21 million pieces; litecoin's upper limit is 84 million pieces yearly. Litecoin's mining prize is 25 LTC (Litecoin, n.d.).

EOS is a cryptocurrency that was released in July 2017 as an initial coin offering (ICO). EOS uses block producers for creating the network instead of a mining mechanism. EOS's purpose is to provide a highspeed transaction network in comparison with Bitcoin and Ethereum. Delegated proof of stake (DPoS) method is another method instead of proof of work which is introduced by EOS management team. Twenty-one (21) block producers are selected by a vote from token holders. Block producers validate transactions and add them to the blockchain. Thus, transactions will be faster as confirmation will not be required from all network nodes (Stergiou, 2019).

Holochain (HOT) is an alternative way to blockchain. In Holochain, each peer in the network stores its data locally within its device, then each of them computes its hash value and share it with all other peers in the network through DeHedge Token (DHT). Instead, blockchain builds big data that stores all transactions within the network inside a group of blocks chaining together (Frahat, Monowar, \& Buhari, 2019). 


\section{Cryptocurrency Exchange}

The cryptocurrency exchange is a platform that provides users with the possibility to exchange cryptocurrencies for other cryptocurrencies and fiat Money (Schueffel et al., 2019). The cryptocurrency market is a digital market where buyers and sellers are brought together without any intermediaries. Cryptocurrencies can be exchanged with other cryptocurrencies or fiat money whenever traders want. These exchange platforms take a commission from buyers and sellers. Mainly, Bitcoin serves as an electronic exchange and also an investment instrument for trading (Dyhrberg, Foley, \& Svec, 2018).

The first type of exchange is called fiat exchange. Buyers and sellers can exchange their fiat money like US dollars, Euros, etc. into cryptocurrencies. An electronic wallet can be issued by the exchange (Kim $\&$ Lee, 2018). The second type of exchange is called cryptocurrency to cryptocurrency exchanges. If a user wants to trade a selected currency pair, he/she needs to create a purchase order at a personally selected price. Investors can also hold cryptocurrency on their exchange balance until a favorable price to sell them on the market (Exmo, n.d.). Table 2 shows ten popular exchange platforms for cryptocurrencies in 2019.

\begin{tabular}{|c|c|c|c|}
\hline $\begin{array}{c}\text { Name } \\
\text { (WebSite) }\end{array}$ & Total Accounts Limit & Security & $\begin{array}{c}\text { Trading } \\
\text { Fee }\end{array}$ \\
\hline Bitfinex & None & 2-FA, SMS Alert & $0.1 \%-0.2 \%$ \\
\hline Cex.io & \$1000/Day & 2-FA, SMS Alert & $\begin{array}{l}0.25 \%- \\
0.16 \%\end{array}$ \\
\hline OKCoin & $\$ 50.000$ for individuals, $\$ 100$ for institutions & 2-FA, Call Verification & $\begin{array}{l}0.05 \%- \\
0.15 \%\end{array}$ \\
\hline Binance & None & $\begin{array}{l}\text { 2-FA, SMS and Mail } \\
\text { Alert, Security Key }\end{array}$ & $0.1 \%$ \\
\hline Coinbase & None & AES-256, Cold Storage & $\begin{array}{l}0.49 \%- \\
3.99 \%\end{array}$ \\
\hline Kraken & None & $\begin{array}{l}\text { 2-FA, SMS and Mail } \\
\text { Alert, Master Key }\end{array}$ & $\begin{array}{l}0.16 \%- \\
0.26 \%\end{array}$ \\
\hline Localbitcoins & None & 2-FA, Login Guard & Changeable \\
\hline Bitstamp & None & $\begin{array}{l}\text { 2-FA, Cold Wallet, Private } \\
\text { Key }\end{array}$ & $\begin{array}{l}0.1 \%- \\
0.25 \%\end{array}$ \\
\hline Gemini & $\begin{array}{l}\text { Maximum } \$ 500 \text { daily, } \$ 15.000 \text { monthly for } \\
\text { individuals; Maximum } \$ 10.000 \text { daily and } \\
\$ 300.000 \text { monthly for businesses }\end{array}$ & $\begin{array}{l}\text { 2-FA, FDIC Insurance for } \\
\text { US Residents, Cold, } \\
\text { Storage }\end{array}$ & $0.25 \%$ \\
\hline Bittrex Global & $\$ 3.000 /$ Day & 2-FA, Cold Wallet & $0.25 \%$ \\
\hline
\end{tabular}

Table 2. Popular 10 Exchange Platforms for The Year 2019

BtcTurk is the first opened Bitcoin exchange platform in Turkey. Also, it is the first platform where Ethereum's buying and selling prices are declared in Turkey. In BtcTurk, all accounts have SMS verification. Systems are protected with cutting edge technologies. The trading fee for the Turkish lira (TL) exchange is calculated according to trade volume for 30 days. The commission rate for a Bitcoin/Tether (BTC/USDT) pair is $0 \%$ and independent from trading volume. Koinim is the first opened Litecoin (LTC) exchange platform in Turkey. Koinim's trading fee is in the range of $0.3 \%-0.4 \%$. Koinim uses two-factor authentication (2-FA) and cold storage security systems. 
Paribu is opened as a platform in 2017 for making Bitcoin trades in Turkey. Its trading fee is in the range of $0 \%-0.35 \%$ and is calculated according to trade volume. Paribu has 2-FA authentication and cold storage security. Koineks is remarkable as the platform that lists one more coin for the first time in Turkey. Koineks' trading fee is in the range of $0.001 \%-0.003 \%$. The fourth exchange platform for virtual currency in Turkey is BitTurk. Vebitcoin and Bitlo are the newest platforms added in the Turkey crypto market. Borsabit is also a new platform in Turkey for initial coin offering of Borsabit Coin (BBC).

In Turkey, when cryptocurrency exchange platforms are compared, it can be seen that Paribu and BtcTurk have been more preferred by consumers who have made Bitcoin trades. These platforms were followed by Bitlo, Koinim, Koineks, Borsabit, BitTurk, and Vebitcoin, respectively (Twentify, 2018).

\section{Developments Related to Cryptocurrency in Turkey}

In Turkey, awareness of cryptocurrencies over time can be seen as Google search trends in Figure 2 (GoogleTrends, 2019). It appears that individuals began to show awareness of cryptocurrencies, especially Bitcoin, after 2016. It is observed that the interest in cryptocurrencies increased due to the record levels of Bitcoin transaction prices reached in December 2017. In 2019, Statista expressed that one person in five had and used cryptocurrencies in Turkey. Thus, Turkey was in the first line, according to other countries, with 20\% participation (Buchholz, 2019). In Turkey, according to Twentify's survey (2018), cryptocurrency users (44\%) prefer cryptocurrencies as an investment instrument.

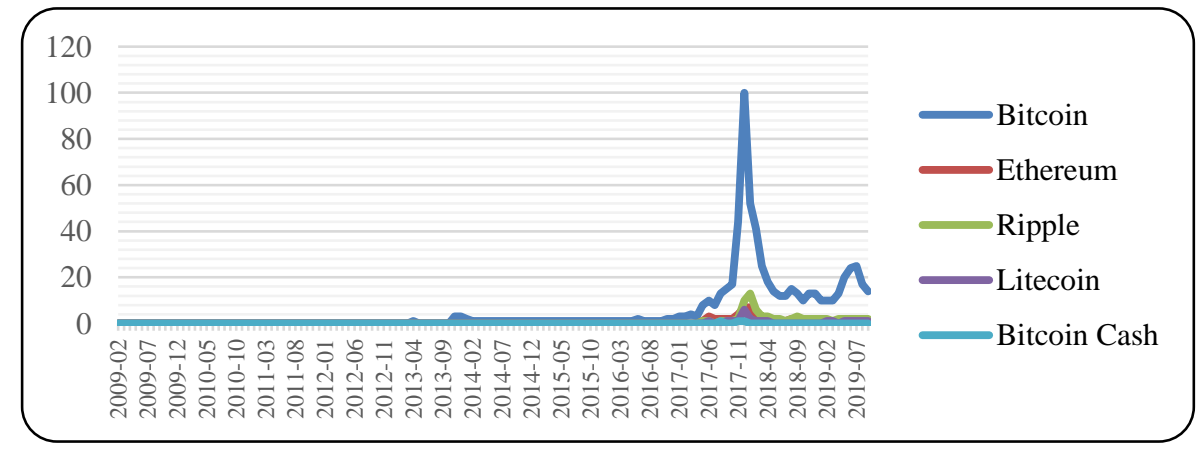

Figure 2. Cryptocurrencies' Search Interest in Turkey Reference: GoogleTrends (2019)

Finance ministers of G-20 countries, which came together in 2018, pointed out those crypto-assets do not threaten global financial stability. Still, they have risks in many ways like customer protection, market reliability, tax evasion etc. The Financial Stability Board (FSB) watches for the effects of cryptoasset markets on global financial stability to eliminate these risks and regulate the markets. The Basel Committee evaluates the risks that banks are exposed to, directly and indirectly, due to crypto assets. The International Organization of Securities Commissions (IOSCO) has developed various proposals to protect investors, ensure the transparent and effective market mechanism and reduce systemic risk (Kahraman, 2019). 
The Capital Markets Board of Turkey (CMBT) reported in December 2017 that investment institutions should not make spot or derivative transactions based on virtual currency with their clients. Also, the CMBT started its activities to create regulations about the crypto money market (Kahraman, 2019). The legal framework to be established will increase the confidence in the market, accelerate the spread of cryptocurrencies and will lead to the growth of the trading volumes of the markets. Like many countries in the world, Turkey planned to put into practice blockchain-based digital central bank money in 2020 (Office of Strategy and Budget Affairs at the Presidency Republic of Turkey).

\section{Technology Acceptance Model Towards Cryptocurrency}

Attitudes about using cryptocurrencies were affected by some factors as categorized in two main titles: perceived benefits (PB) and perceived risks (PR). PB reflects an individual's positive perceptual belief about using cryptocurrencies. In the other direction, PR expresses negative and uncertain perceptual beliefs about using cryptocurrencies.

Davis, Bagozzi, and Warshaw (1989) used the technology acceptance model (TAM) to explain computer usage behavior. TAM was later extended by Venkatesh and Davis (2000), Venkatesh, Morris, Davis, and Davis (2003) and Featherman and Pavlou (2003). The purpose of TAM is to explain the determinants of computer acceptance that is general and capable of explaining user behavior across a broad range of end-user computing technologies and user populations. TAM was created to identify basic variables about cognitive and affective determinants of computer acceptance. Theory of reasoned action (TRA) and theory of planned behaviour (TPB) is used by TAM as basis for modeling the relations between variables (Rondan-Cataluña, Arenas-Gaitán, \& Ramírez-Correa, 2015). TAM uses TRA and TPB to explain causal relations between belief-attitude, intention-behavior. Simpleness, explanatory power and ease of use in different information system researches are the advantages of TAM for the common choice as a theoretical framework. The TAM model has been worked for many different research areas: e-commerce, online banking, mobile payment services, online shopping (Fortes \& Rita, 2016; Verkijika, 2020), crowdfunding and mobile microfinance services. Cryptocurrency usage behavior in Turkey is a subject that has not been researched before. TAM is suitable as it supports designing consistent measurement for a newly research areas (Abramova \& Böhme, 2016).

Intentions about using cryptocurrency and the factors that affect usage of cryptocurrencies were recently studied by researchers. Featherman and Pavlou (2003) tried to integrate TAM with the e-services adoption model. Krombholz, Judmayer, Gusenbauer, and Weippl (2017) surveyed Bitcoin users to specify safety, privacy and anonymity in the Bitcoin network. They found that managing bitcoins is a significant challenge for many users. Abramova and Böhme (2016) integrated the TAM model on usage of Bitcoin. They indicated in their study that Bitcoin users were concerned about regulatory restrictions for transactions about cryptocurrencies. Additionally, perceived ease of use was determined to have the weakest effect on system use. Walton and Johnston (2018) studied the factors about Bitcoin usage in 
South Africa in their study. They found that Bitcoin acceptance in South Africa was significantly and directly influenced by perceived benefits, perceived social influences and attitudes.

Mendoza-Tello, Mora, Pujol-López, and Lytras (2018) analyzed cryptocurrency usage for digital payments in social media. The results showed that perceived usefulness was the most effective factor in the intention to use cryptocurrencies for electronic payments. Shahzad, Xiu, Wang, and Shahbaz (2018) found that awareness, perceived trustworthiness, perceived usefulness and perceived ease of use have a significant positive relation with the intention to use Bitcoin in China. Arias-Oliva, Pelegrín-Borondo, and Matías-Clavero (2019) analyzed the key factors for the successful development of a cryptocurrency from a consumer behavior point of view. Their structured online survey was to Spanish people who were over 20 years old and had a university degree. They found that perceived risk of cryptocurrency transactions was very high and the existence of an easily accessed helpdesk in case of problems were all important factors that could affect cryptocurrency acceptance. Sobhanifard and Sadatfarizani (2019) determined technological abilities, technological uncertainty and technological advantages factors about using cryptocurrencies. In this study, the Abramova and Böhme (2016) model was used to measure the user behavior of individuals as shown in Figure 3. In their model, three main factors affected individuals' usage behavior: perceived benefit, perceived ease of use (PEU) and perceived risk. Perceived benefit includes three sub-factors: 1) transaction factor (TF), 2) security and control factor (SCF), and 3) decentralization factor (DF).

TF reflects the benefits of the transaction for using cryptocurrencies. In an electronic payment system, users don't need intermediaries. So, payments with cryptocurrencies can be made at a minimum or no financial cost to the two parties engaged in a payment transfer. Cryptocurrencies can be kept or spent if counterparts accept them as payment in a transaction or exchanged for official currencies (Weber, 2014).

SCF states individuals' opinions about overall security for cryptocurrencies in the payment system. Cryptocurrencies provide security by using a public key cryptography system. Only the owner of the private key can make a transaction. Contrary to credit cards, Bitcoin doesn't expose the private key when making a transaction and are free from chargebacks. If Bitcoins are sent to the counterpart, the transaction cannot be moved back (Conti, Kumar, Lal, \& Ruj, 2018).

DF indicates benefits for cryptocurrencies' working mechanism. Blockchain started a new age for the global financial system with the emergence of cryptocurrency and its effect was felt in other relevant industries. The most important benefit of blockchains, especially in financial systems, is the use of cryptocurrency (Narman et al., 2018). Blockchain wallet numbers have been increasing since the production of Bitcoin in 2009 and reach more than 42 million blockchain wallet users in June 2019 (Szmigiera, 2020). Blockchain technology is designed to achieve decentralization. Thus, users make a transaction between each other directly (peer to peer), anonymously and transparently (Hassani, Huang, \& Silva, 2018). PEU shows benefit about learning and using cryptocurrencies easily. In other words, 
PEU indicates freedom from difficulty or great effort and affects perceived benefit (Fornell \& Larcker, 1981).

Perceived risk sub-factors were determined as 1) legal risk factor (LRF), 2) operational risk factor (ORF), and 3) adoption risk factor (ARF). According to Kuisma, Laukkanen, and Hiltunen (2007), many individuals are afraid of losing their money while sending and receiving money over the internet. Especially if the cryptocurrency code is lost or stolen, cryptocurrency will be gone forever. LRF includes unclear legal status of using cryptocurrencies from the standpoint of various countries, and there isn't any universal regulation about cryptocurrencies all over the world. Regulatory uncertainty into cryptocurrencies creates significant problems with consumer protection. Currency refers to the banknotes and coins that are issued by a central authority like the central bank. Currencies are given the legal status of legal tender under the state's legal framework. Money is broader than currencies, and it can be created by central banks (He et al., 2016). On the other hand, cryptocurrencies are created by private institutions or persons. Some countries have decided to ban the use of cryptocurrencies.

ORF states potential risks about the internal working process of the system or personal mistakes. Double spending is one of the most significant operational risk losses. Hardware safety is necessary for processing and confirmation in the cryptocurrency networks and is an important factor for operational risk. Software rollout defects and protocol update disruptions are another operational risk factor (Peters, Chapelle, \& Panayi, 2016).

ARF represents uncertainties about cryptocurrencies' acceptance by merchants. Cryptocurrencies fulfill the three traditional functions of money: medium of exchange, store of value and unit of account. The medium of exchange arises when cryptocurrency is purchased by someone for the purpose of selling it in exchange for another good. Cryptocurrencies must be held in digital wallets. Digital wallet companies suggest transferring cryptocurrencies offline into cold storage and these transfers cause additional fees (Yermack, 2015). Cryptocurrencies can achieve this function on online exchanges. Floating demand, inflexible supply and decentralization factor make cryptocurrencies inadequate as a unit of account (Ammous, 2018).

According to previous studies, the following hypotheses were proposed:

H1: Perceived benefit influences users' engagement in cryptocurrency transactions positively.

H2: Perceived ease of use influences users' engagement in cryptocurrency transactions positively.

H3: Perceived ease of use influences the perceived benefit of cryptocurrency positively.

H4: Perceived risk influences users' engagement in cryptocurrency transactions negatively. 


\section{ANALYSIS}

\section{Source of Data}

This study aims to determine the effects of perceived ease of use, perceived benefit, and perceived risk on Turkish individuals' usage behavior about cryptocurrencies. In the study, convenience sampling method was used, and three hundred twenty (320) participants were reached through social media platforms. For measuring attitudes of participants about using crypto currencies, a survey was advertised on Twitter. The survey was created in Google Forms and filled out by knowledgeable participants who are interested in or use crypto currency on online platforms (mostly via Twitter). Questionnaires were evaluated which all of the questions were answered by participants. According to Westland (2015) formula, minimum sample size in structural equation model estimation for this study must be a hundred (100). Kline (2016) recommended that if $\mathrm{n} / \mathrm{q}$ ratio is equal to 20 , the sample size is ideal; $\mathrm{n} / \mathrm{q}$ ratio equal to 10 is realistic (acceptable) and n/q ratio equal to 5 is acceptable only if the loads are high (>0.50). " $n$ " means sample size and " $q$ " represents the parameter number in the ratio. The minimum sample size for the model will be $\mathrm{N}=10 \times 20$ two hundred (200). The survey was published between 3rd of July -18th of September 2019. When it was determined that sufficient sample size was reached, data collection process was terminated and a total of 320 usable questionnaires were obtained. Survey questions were prepared with the help of some studies: Featherman and Pavlou (2003), Cheng, Lam, and Yeung (2006), Abramova and Böhme (2016), Walton and Johnston (2018). Three hundred twenty (320) participants filled out the questionnaire and their survey results were evaluated. Analysis results and discussions were limited by the sample, and this was the main constraint of the study. The study was conducted with approval of the University of Kocaeli Ethics Board.

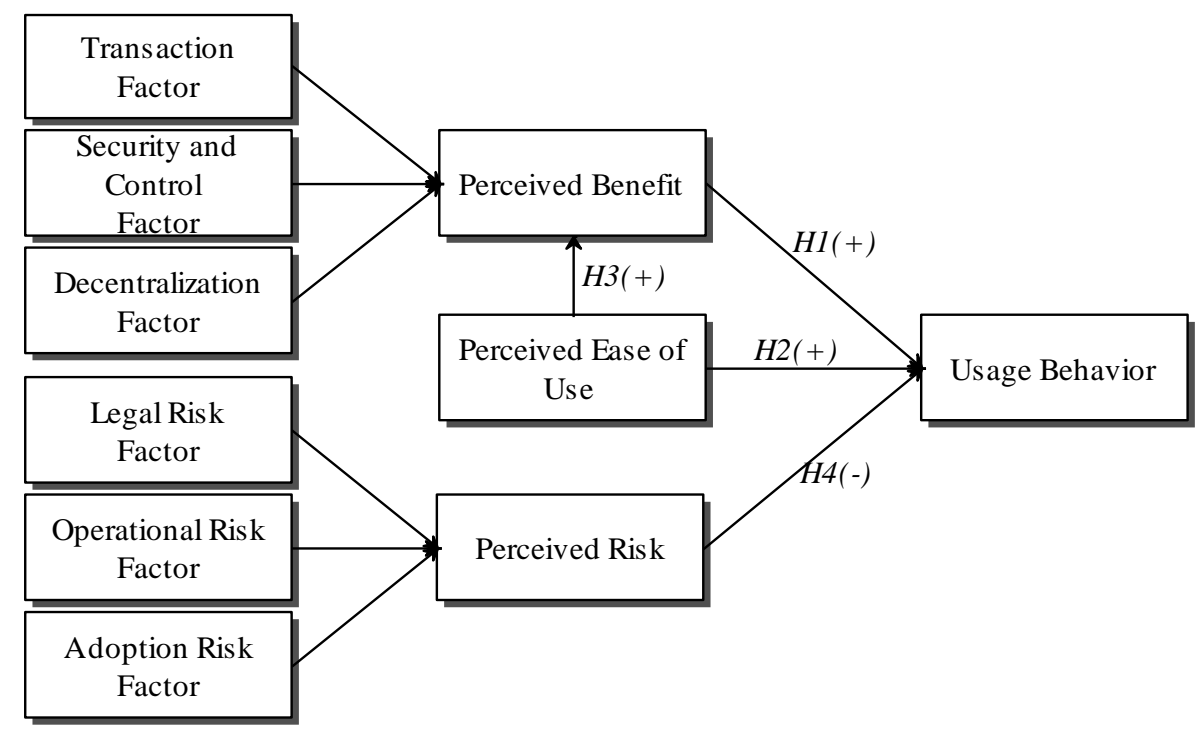

Figure 3. Research Model 
The survey was designed in three parts. In the first part, demographic results were tried to be determined. In the second part, questions were prepared for participants to determine their awareness and usage of cryptocurrencies. In the last part (as seen in Tablo 9), eighteen expressions were prepared with a Likert Scale to measure some factors about using cryptocurrencies. In Table 4, 320 participants' demographic characteristics can be seen.

Table 3. References from The Literature for Model's Factors and The Hypotheses

\begin{tabular}{|c|c|c|c|}
\hline Hidden Factors & Observed Factors & References & Hypotheses \\
\hline $\begin{array}{l}\text { Perceived Benefit } \\
\qquad(\mathrm{PB})\end{array}$ & $\begin{array}{c}\text { Transaction Factor (TF) } \\
\text { Security and Control } \\
\text { Factor (SCF) } \\
\text { Decentralization Factor } \\
\text { (DF) }\end{array}$ & $\begin{array}{l}\text { Abramova and Böhme (2016), Walton } \\
\text { and Johnston (2018) }\end{array}$ & $H_{1}$ \\
\hline Perceived Risk (PR) & $\begin{array}{c}\text { Operational Risk Factor } \\
\text { (ORF) } \\
\text { Legal Risk Factor (LRF) } \\
\text { Adoption Risk Factor } \\
\text { (ARF) }\end{array}$ & $\begin{array}{c}\text { Featherman and Pavlou (2003), Walton } \\
\text { and Johnston (2018), } \\
\text { Abramova and Böhme (2016) }\end{array}$ & $\mathrm{H}_{4}$ \\
\hline $\begin{array}{l}\text { Perceived Ease of } \\
\text { Use (PEU) }\end{array}$ & & $\begin{array}{c}\text { Cheng et al. (2006), Walton and } \\
\text { Johnston (2018) }\end{array}$ & $H_{2}, H_{3}$ \\
\hline
\end{tabular}

Table 4. Demographics of Respondents

\begin{tabular}{lrr}
\hline Variable & Observations (Number) & \multicolumn{1}{c}{$\%$} \\
\hline Gender & 301 & \\
Male & 19 & $94.1 \%$ \\
Female & & $5.9 \%$ \\
\hline Marital Status & 188 & \\
Married & 132 & $58.8 \%$ \\
Single & & $41.2 \%$ \\
\hline Education & 1 & \\
Literate & 6 & $0.3 \%$ \\
Elementary School & 30 & $1.9 \%$ \\
High School & 218 & $9.4 \%$ \\
College & 65 & $68.1 \%$ \\
Master - PHD & & $20.3 \%$ \\
\hline Age & 41 & \\
18-25 & 104 & $12.8 \%$ \\
26-33 & 136 & $32.5 \%$ \\
$\mathbf{3 4 - 4 3}$ & 26 & $42.5 \%$ \\
$\mathbf{4 4 - 5 1}$ & 13 & $8.1 \%$ \\
$\mathbf{5 2 +}$ & & $4.1 \%$ \\
\hline Income Level (Monthly) & 138 & \\
$\mathbf{0}-\mathbf{5 . 0 0 0}$ TL & 109 & $43.1 \%$ \\
$\mathbf{5 . 0 0 1 - 1 0 . 0 0 0 ~ T L}$ & 36 & $34.1 \%$ \\
$\mathbf{1 0 . 0 0 1 - 1 5 . 0 0 0}$ TL & 18 & $11.3 \%$ \\
$\mathbf{1 5 . 0 0 1 - 2 0 . 0 0 0}$ TL & 19 & $5.6 \%$ \\
$\mathbf{2 0 . 0 0 1 +}$ & 320 & $5.9 \%$ \\
\hline \hline Total & & \\
& &
\end{tabular}




\section{Methodology}

Structural equation (regression) modeling (SEM) was used to test the research model. SEM is an approach used to model complex multivariate relations between observed and hidden variables, testing the results of confirmatory factor analysis and path analysis together (Fornell \& Bookstein, 1982; Yilmaz, Can, \& Aras, 2021). Confirmatory factor analysis is a process for creating hidden variable (factor) based on observed variables through a previously created model. Path analysis assumes that the relationships between variables are linear, additive and causal. For this reason, there are no nonlinear and interactive relationships. Path analysis examines cause-effect relationship by using correlation and regression data. In other word, while trying to verify by testing theoretical causality, causality is tried to be discovered. In path analysis, the effects of variables on each other are given with a path diagram. Thus, it is ensured that the ways are better understood and it enables to see the variables or relationships that have been forgotten to be included in the model (Karagöz, 2016). In this study, the reason for using the SEM in the analysis is the desire to define the covariance-based causality (relationship) between the observed and hidden variables. Validity- reliability and factor analysis were conducted using SPSS 22. AMOS 24 program was used for SEM. When the data is examined, it is normally distributed according to Tabachnick, Fidell, and Ullman (2007), as it is in the range of \pm 1.5 with skewness (max 0.891) and kurtosis (max 1.114) values. A parametric analysis was made according to this information.

\section{Validity and Reliability}

Cronbach's alpha was found $83 \%$ for the model. This value was higher than $70 \%$, so the survey scale could be accepted as valid. The Bartlett test value was found to be 2031.284, significance 0.00 . KaiserMayer-Olkin (KMO) value was found to be 0.84 . If KMO value is above 0.60 , this shows that the sample size is sufficient.

According to Fornell and Larcker (1981), three criteria must be verified for convergent validity: 1) indicator factor loadings should be statistically meaningful and be more than 0.5.; 2) construct reliabilities (CR) should be more than 0.7 ; and 3) average variance extracted (AVE) should be more than 0.5. In Table 4, it can be seen that factor loadings were higher than 0.50 and all CR were higher than 0.70. Additionally, CR scores were found higher than AVE scores for all factors. All Cronbach's alpha scores were found to be 0.70 and higher except for the decentralization factor. All other decentralization factor criteria results were significant, and model's Cronbach's alpha score was 0.827 . For these reasons, decentralization factor was added into the analysis. So, all of these factors can be expressed as proof of convergent validity. 
Table 5. Results of Factor Analysis

\begin{tabular}{|c|c|c|c|c|c|}
\hline Factors & Item & $\begin{array}{l}\text { Factor } \\
\text { Loading }\end{array}$ & CR & AVE & $\begin{array}{l}\text { Cronbach } \\
\text { 's Alpha }\end{array}$ \\
\hline \multirow{3}{*}{$\begin{array}{c}\text { Transaction } \\
\text { Factor }\end{array}$} & $\mathrm{TF}_{1}$ & 0.77 & \multirow{3}{*}{0.81} & \multirow{3}{*}{0.59} & \multirow{3}{*}{0.70} \\
\hline & $\mathrm{TF}_{2}$ & 0.77 & & & \\
\hline & $\mathrm{TF}_{3}$ & 0.76 & & & \\
\hline Security and & $\mathrm{SCF}_{1}$ & 0.83 & \multirow{2}{*}{0.82} & \multirow{2}{*}{0.70} & \multirow{2}{*}{0.81} \\
\hline Control Factor & $\mathrm{SCF}_{2}$ & 0.84 & & & \\
\hline Decentralization & $\mathrm{DF}_{1}$ & 0.68 & \multirow{2}{*}{0.72} & \multirow{2}{*}{0.57} & \multirow{2}{*}{0.65} \\
\hline Factor & $\mathrm{DF}_{2}$ & 0.82 & & & \\
\hline Operational Risk & $\mathrm{ORF}_{1}$ & 0.76 & \multirow{3}{*}{0.72} & \multirow{3}{*}{0.56} & \multirow{3}{*}{0.85} \\
\hline \multirow[t]{2}{*}{ Factor } & $\mathrm{ORF}_{2}$ & 0.74 & & & \\
\hline & $\mathrm{LRF}_{1}$ & 0.81 & & & \\
\hline Legal Risk Factor & $\mathrm{LRF}_{2}$ & 0.81 & \multirow{2}{*}{0.77} & \multirow{2}{*}{0.53} & \multirow{2}{*}{0.77} \\
\hline & $\mathrm{LRF}_{3}$ & 0.54 & & & \\
\hline Adoption Risk & $\mathrm{ARF}_{1}$ & 0.83 & \multirow{2}{*}{0.80} & \multirow{2}{*}{0.66} & \multirow{2}{*}{0.71} \\
\hline Factor & $\mathrm{ARF}_{2}$ & 0.80 & & & \\
\hline Perceived Ease of & $\mathrm{PEU}_{1}$ & 0.72 & \multirow{2}{*}{0.76} & \multirow{2}{*}{0.62} & \multirow{2}{*}{0.73} \\
\hline Use & $\mathrm{PEU}_{2}$ & 0.85 & & & \\
\hline \multirow{2}{*}{\multicolumn{6}{|c|}{$\begin{array}{c}\text { Total Explained Variance: } 77.046 \\
\text { KMO Test Result: } 0.84\end{array}$}} \\
\hline & & & & & \\
\hline \multicolumn{3}{|c|}{ Bartlett's Test Result: 2031.284} & \multicolumn{2}{|c|}{ Significance: .00 } & \\
\hline
\end{tabular}

Fornell and Larcker (1981) criterion requires the square root of AVE of each construct to be greater than its highest correlation with any other construct. Table 6 shows that this requirement was satisfied (Abramova \& Böhme, 2016; Hair, Hult, Ringle, \& Sarstedt, 2014).

Table 6. Correlation Matrix and The Square Roots of Ave Values (In Bold)

\begin{tabular}{cccccccc}
\hline Construct & TF & SCF & DF & ORF & LRF & ARF & PEU \\
\hline \hline TF & $\mathbf{0 . 7 6 8 1 1 5}$ & & & & & & \\
SCF & 0.447 & $\mathbf{0 . 8 3 6 6 6}$ & & & & & \\
DF & 0.415 & 0.548 & $\mathbf{0 . 7 5 4 9 8 3}$ & & & & \\
ORF & 0.025 & 0.022 & 0.024 & $\mathbf{0 . 7 4 8 3 3 1}$ & & & \\
LRF & 0.095 & 0.016 & 0.066 & 0.67 & $\mathbf{0 . 7 2 8 0 1 1}$ & & \\
ARF & -0.031 & -0.046 & 0.015 & 0.563 & 0.517 & $\mathbf{0 . 8 1 2 4 0 4}$ & \\
PEU & 0.446 & 0.488 & 0.555 & 0.072 & 0.124 & 0.006 & $\mathbf{0 . 8 1 2 4 0 4}$ \\
\hline
\end{tabular}


Table 7. The Research Model Fit Indices

\begin{tabular}{lccc}
\hline Fit Indices & Index Value & Model Fit Criterion Thresholds & Interpretation \\
\hline x2/df (x2=193.132, df. =122) & 2.845 & $x^{2} / d f \leq 3$ & Excellent \\
GFI & 0.956 & $\geq 0.90$ & Excellent \\
CFI & 0.957 & $\geq 0.95$ & Excellent \\
NFI & 0.936 & $\geq 0.90$ & Excellent \\
AGFI & 0.921 & $\geq 0.90$ & Excellent \\
RMSEA & $\mathbf{0 . 0 7 6}$ & $\leq \mathbf{0 . 0 8}$ & Excellent \\
\hline
\end{tabular}

\section{Discussion and Results}

Amos 24 was used to compute structural model and path analysis's fit indices. In Table 7, the calculated model fit indices indicate that the research model is suitable for path analysis.

TF, DF and PEU had significant effect on usage behavior. It was found that SCF had no significant impact on user behavior about cryptocurrencies. PB had a positive, significant, and direct effect on user behavior. At the same time, PEU had a statistically significant but reverse direction effect on user behavior.

A causality relation between PB and DF was found, according to TF and SCF. In this case, it can be said that the participants found the cryptocurrencies useful because they did not like the traditional financial system, and they did not have to rely on authority. This result is inconsistent with Abramova and Böhme (2016). The reason may be a geographic location or national issue. Especially increase in trade wars between countries in recent years may have strengthened the benefit factor of cryptocurrency, which has a decentralized structure. This results in explaining $49 \%$ of the regression $\left(\mathrm{R}^{2}\right)$ in PB by TF, SCF, DF, and PEU that had a direct and significant impact on UB. As a result, the $\mathrm{H}_{1}$ hypothesis was supported. If cryptocurrency usage is desired to be increased to a high level, ease of use should be emphasized. Because of their complex structures and the difficulty in understanding them, participants may be reluctant to use cryptocurrencies. Although PEU had an impact on UB at statistically significance level, the $\mathrm{H}_{2}$ hypothesis was not supported as a result of the negative relationship between them. In a similar way, Abramova and Böhme (2016) indicated in their study that perceived ease of use was determined to have the weakest effect on system use. PEU positively and significantly affected PB at the 0.001 significance level; thus, the $\mathrm{H}_{3}$ hypothesis was supported as a result. If the $\mathrm{H}_{2}$ and $\mathrm{H}_{3}$ hypotheses are evaluated together, it can be said that PEU had no positive direct relation with UB. On the other hand, results showed that PEU had a positive relation with PB in the study.

LRF, ORF and ARF had a significant effect on PR at the 0.001 significance level. PR did not make any significant effect on UB. $\mathrm{H}_{4}$ hypothesis was not supported as a result. This result is consistent with 
Mendoza-Tello et al. (2018). Despite security vulnerabilities, losses to be experienced, legal uncertainties, possible government interventions, contract deficits, system errors, and long-term uncertainties, this situation did not affect UB negatively. Participants prefer to use cryptocurrencies by taking these risks. In the model, PB, PEU and PR explained 57\% of the regression $\left(\mathrm{R}^{2}\right)$ about $\mathrm{UB}$. Table 8 shows the summaries about the estimation results for the hypotheses.

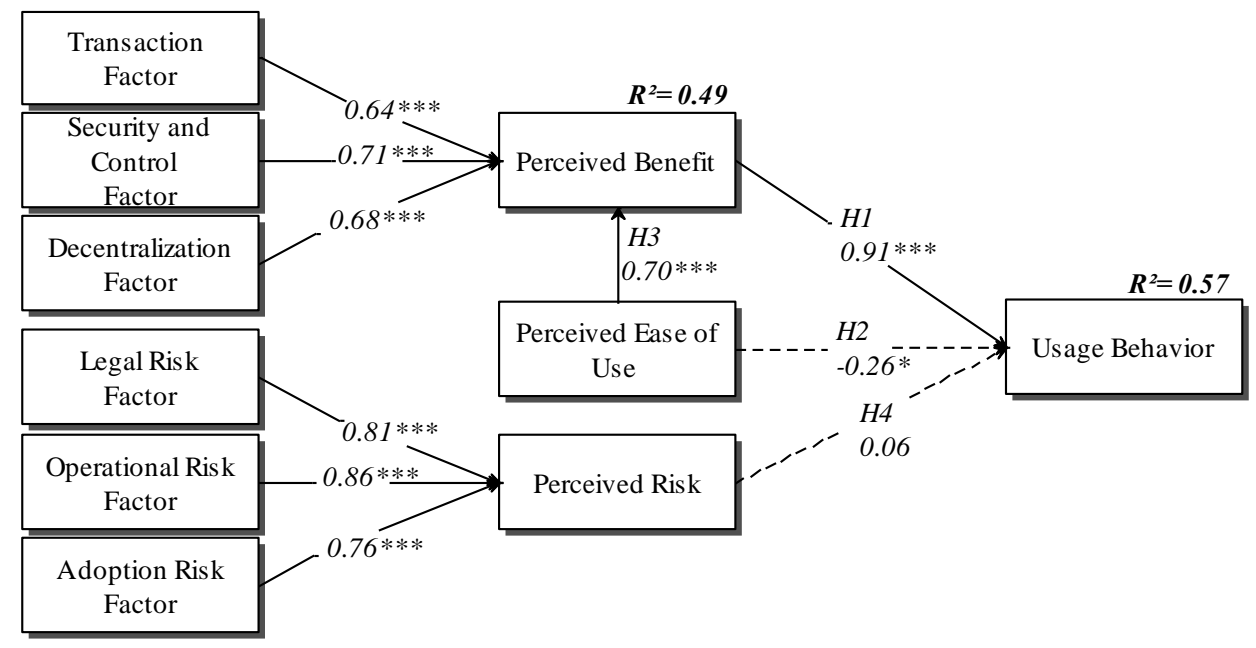

Figure 4. Path Analysis Results

Table 8. Estimation Results of Structural Model

\begin{tabular}{lcccc}
\hline \multicolumn{1}{c}{ Relationship } & Hyp. & Path Coefficient & Stan. Error & Result \\
\hline \hline Perceived Benefit $\rightarrow$ Usage Behavior & $H_{1}$ & $0.91^{* * *}$ & 0.121 & Supported \\
\hline Perceived Ease of Use $\rightarrow$ Usage Behavior & $H_{2}$ & $-0.26^{*}$ & 0.062 & Not Supported \\
\hline Perceived Ease of Use $\rightarrow$ Perceived Benefit & $H_{3}$ & $0.70^{* * *}$ & 0.044 & Supported \\
\hline Perceived Risk $\rightarrow$ Usage Behavior & $H_{4}$ & 0.06 & 0.033 & Not Supported \\
\hline
\end{tabular}

\section{CONCLUSIONS}

This study aimed to determine why Turkish participants are voluntary or hesitant to use cryptocurrencies and to assess which factors affected cryptocurrencies usage. Cryptocurrency usage behavior in Turkey is a subject that has not been researched before. Three hundred twenty (320) participants in Turkey completely filled out the questionnaire through Twitter and their survey responses were evaluated for results.

Analysis results and discussions were limited by the sample characteristics, which was the main constraint of the study. TAM was used in the study to analyze Turkish individuals' cryptocurrency usage behavior. 
The study model showed that cryptocurrency usage was exposed to the most effect by perceived benefit in comparison with PEU and perceived risk. A causality relation between perceived benefit and decentralization factor was found more than other benefit sub-factors. This result is inconsistent with Abramova and Böhme (2016). In this case, it can be said that the participants found the cryptocurrencies useful because they did not like the traditional financial system, and they did not have to rely on authority. Contrary to expectations, perceived risk did not make any meaningful effect on usage behavior. This result is similar with Mendoza-Tello et al. (2018). Also, participants' answers showed that legal, operational and adoption risk factors influenced perceived risk in the survey. Participants were aware of these risks and prefer to use cryptocurrencies by taking these risks.

The 2008 global financial crisis created losses of trust in financial institutions, especially banks. On the other hand, the rapid improvement of internet-based technologies has revealed the possibilities to make financial transactions in financial markets without intermediaries and with cryptocurrencies.

PEU had no positive direct relation with usage behavior in the study. There can be some reasons that can explain these results. First, survey participants in the study consisted of cryptocurrency users and people interested in cryptocurrencies. Second, participants mostly represented a highly educated (88.4\%) and experienced middle-aged (75\%) group. They were adequately trained in topics related to cryptocurrencies.

Therefore, participants may have been thinking that cryptocurrencies can be used easily and do not require much mental or learning effort. The results showed that PEU had a positive relationship with perceived benefit in the study. This result is consistent with Gunawan and Novendra (2017). Variables about performance expectancy and facilitating conditions may be the factors most affecting the participants about cryptocurrency technology.

Since crypto money markets, which constitute a new option in financial markets, are still in a systematic development and acceptance process, attitudes towards crypto money are a matter of curiosity. Considering the developments in the world and Turkey about cryptocurrencies, it was observed that their use and interest are widespread and growing. This research contributes to determining Turkish cryptocurrency users' behavior. Previous studies were generally measured attitudes towards Bitcoin. In this research, many more cryptocurrency types were tried to be generally evaluated. Future research could describe similarities or differentiations for different nationalities about cryptocurrency users' behavior that were determined in this research model. In new studies, the purpose of using cryptocurrencies and stock market preference factors could be investigated with open-ended questions.

Declaration of Interests: On behalf of all authors, the corresponding author states that there is no conflict of interest. 


\section{REFERENCES}

Abramova, S., \& Böhme, R. (2016). Perceived Benefit and Risk as Multidimensional Determinants of Bitcoin Use: A Quantitative Exploratory Study. Paper presented at the ICIS.

Ahamad, S., Nair, M., \& Varghese, B. (2013). A survey on crypto currencies. Paper presented at the 4th International Conference on Advances in Computer Science, AETACS.

Akyildirim, E., Corbet, S., Lucey, B., Sensoy, A., \& Yarovaya, L. (2020). The relationship between implied volatility and cryptocurrency returns. Finance Research Letters, 33, 101212. Retrieved from $\quad$ https://www.sciencedirect.com/science/article/pii/S1544612319303381. doi:https://doi.org/10.1016/j.frl.2019.06.010

Ammous, S. (2018). Can cryptocurrencies fulfil the functions of money? The Quarterly Review of Economics and Finance, 70, 38-51. Retrieved from https://www.sciencedirect.com/science/article/pii/S1062976917300777. doi:https://doi.org/10.1016/j.qref.2018.05.010

Arias-Oliva, M., Pelegrín-Borondo, J., \& Matías-Clavero, G. (2019). Variables influencing cryptocurrency use: A technology acceptance model in Spain. Frontiers in Psychology, 10(475). Retrieved from https://www.frontiersin.org/article/10.3389/fpsyg.2019.00475. doi:10.3389/fpsyg.2019.00475

Authority, T. E. B. (2014, July 4). The European Banking Authority Opinion on 'Virtual Currencies'. [EBA].

from https://www.eba.europa.eu/sites/default/documents/files/documents/10180/657547/81409b944222-45d7-ba3b-7deb5863ab57/EBA-Op-201408\%200pinion\%20on\%20Virtual\%20Currencies.pdf?retry=1

Bank, E. C. (2019, June ). European Central Bank: Crypto-Assets - Trends and Implications. [ECB]. from online/2019/html/1906_crypto_assets.en.html

Binance. (n.d.). Cryptocurrency Exchange. Retrieved October 12, 2019, from https://www.binance.com/en

Bindseil, U. (2019). Central bank digital currency: Financial system implications and control. International Journal of Political Economy, 48(4), 303-335. Retrieved from https://dx.doi.org/10.1080/08911916.2019.1693160. doi:10.1080/08911916.2019.1693160

Bitfinex. (n.d.). Borsa ve Marjin Ticaret Platformu. Retrieved October 12, 2019, from https://www.bitfinex.com/

Bitlo. (n.d.). Kripto Para Borsas1 Nedir? Retrieved December 11, 2019, from https://www.bitlo.com/rehber/kripto-para-borsasi-nedir

Bitstamp. (n.d.). Buy and sell Bitcoin and Ethereum. Retrieved October 12, 2019, from https://www.bitstamp.net/

BittrexGlobal. (n.d.). The Next Generation Crypto-Currency Exchange. Retrieved October 15, 2019, from https://global.bittrex.com/

BitTurk. (n.d.). Türkiye'nin Bitcoin ve Kripto Para Platformu. Retrieved November 11, 2019, from https://bitturk.com/

Borsabit. (n.d.). Türkiye'nin Bitcoin ve Altcoin Borsas1. Retrieved November 11, 2019, from https://borsabit.com/

BtcTurk. (n.d.). Bitcoin ve Kripto Para Alım Satım Platformu. Retrieved November 11, 2019, from https://www.btcturk.com/ 
Buchholz, K. (2019, 17 March). Chart: How Common is Crypto? Retrieved from https://www.statista.com/chart/18345/crypto-currency-adoption/

Bullmann, D., Klemm, J., \& Pinna, A. (2019). In search for stability in crypto-assets: Are stablecoins the solution? . ECB Occasional Paper, 230. Retrieved from https://papers.ssrn.com/sol3/papers.cfm?abstract id=3444847 doi:10.2866/969389

Cex.io. (n.d.). Bitcoin Exchange. Retrieved October 18, 2019, from https://cex.io/

Cheng, T. C. E., Lam, D. Y. C., \& Yeung, A. C. L. (2006). Adoption of internet banking: An empirical study in Hong Kong. Decision Support Systems, 42(3), 1558-1572. Retrieved from https://www.sciencedirect.com/science/article/pii/S0167923606000066.

doi:https://doi.org/10.1016/j.dss.2006.01.002

Coinbase. (n.d.). Bitcoin, Ethereum ve daha fazlasını güvenle alıp satın. Retrieved October 18, 2019, from https://www.coinbase.com/

Coinmarketcap. (n.d.). Cryptocurrency Market Capitalizations. Retrieved December 30, 2019, from https://coinmarketcap.com/

Conti, M., Kumar, E. S., Lal, C., \& Ruj, S. (2018). A survey on security and privacy issues of bitcoin. IEEE Communications Surveys \& Tutorials, 20(4), 3416-3452. doi:10.1109/COMST.2018.2842460

Corbet, S., Meegan, A., Larkin, C., Lucey, B., \& Yarovaya, L. (2018). Exploring the dynamic relationships between cryptocurrencies and other financial assets. Economics Letters, 165, 28 34. Retrieved from https://www.sciencedirect.com/science/article/pii/S0165176518300041. doi:https://doi.org/10.1016/j.econlet.2018.01.004

Office of Strategy and Budget Affairs at the Presidency Republic of Turkey. (2019). 2020 Presidency Annual Programme. [4 Kasım 2019 tarihli ve 30938 Mükerrer Sayılı Resmi Gazete'de yayımlanmıştır] Retrieved from https://www.sbb.gov.tr/wpcontent/uploads/2019/11/2020_Yili_Cumhurbaskanligi_Yillik_Programi.pdf

Çarkacioğlu, A. (2016). Kripto-Para Bitcoin (1130). Retrieved from Sermaye Piyasası Kurulu Araştırma Dairesi Araştırma Raporu. https://www.spk.gov.tr/SiteApps/Yayin/YayinGoster/1130

Davis, F. D., Bagozzi, R. P., \& Warshaw, P. R. (1989). User acceptance of computer technology: A comparison of two theoretical models. Management Science, 35(8), 982-1003. Retrieved from https://pubsonline.informs.org/doi/abs/10.1287/mnsc.35.8.982. doi:10.1287/mnsc.35.8.982

Dyhrberg, A. H., Foley, S., \& Svec, J. (2018). How investible is Bitcoin? Analyzing the liquidity and transaction costs of Bitcoin markets. Economics Letters, 171, 140-143. Retrieved from https://www.sciencedirect.com/science/article/pii/S0165176518302921. doi:https://doi.org/10.1016/j.econlet.2018.07.032

Exmo. (n.d.). Cryptocurrency Exchange. Retrieved October 12, 2019, from https://exmo.com/en/

Featherman, M. S., \& Pavlou, P. A. (2003). Predicting e-services adoption: a perceived risk facets perspective. International Journal of Human-Computer Studies, 59(4), 451-474. Retrieved from https://www.sciencedirect.com/science/article/pii/S1071581903001113. doi:https://doi.org/10.1016/S1071-5819(03)00111-3

Fornell, C., \& Bookstein, F. L. (1982). Two structural equation models: LISREL and PLS applied to consumer exit-voice theory. Journal of Marketing Research, 19(4), 440-452. Retrieved from https://journals.sagepub.com/doi/abs/10.1177/002224378201900406.

doi:10.1177/002224378201900406 
Fornell, C., \& Larcker, D. F. (1981). Evaluating structural equation models with unobservable variables and measurement error. Journal of Marketing Research, 18(1), 39-50. Retrieved from https://journals.sagepub.com/doi/abs/10.1177/002224378101800104. doi:10.1177/002224378101800104

Fortes, N., \& Rita, P. (2016). Privacy concerns and online purchasing behaviour: Towards an integrated model. European Research on Management and Business Economics, 22(3), 167-176. Retrieved from https://www.sciencedirect.com/science/article/pii/S2444883416300134. doi:https://doi.org/10.1016/j.iedeen.2016.04.002

Frahat, R. T., Monowar, M. M., \& Buhari, S. M. (2019, 1-3 May 2019). Secure and Scalable Trust Management Model for IoT P2P Network. Paper presented at the 2019 2nd International Conference on Computer Applications \& Information Security (ICCAIS).

Gemini. (n.d.). The Regulated Cryptocurrency Exchange. Retrieved October 21, 2019, from https://gemini.com/

GoogleTrends. (2019, October). Bitcoin, ethereum, ripple, litecoin, bitcoin cash. from https://trends.google.com.tr/trends/explore?date=2009-01-03\%202019-1003\&geo=TR\&q=Bitcoin, ethereum,ripple,litecoin,bitcoin\%20cash

Gunawan, F. E., \& Novendra, R. (2017). An analysis of bitcoin acceptance in Indonesia. ComTech: Computer, Mathematics and Engineering Applications, 8(4), 241. Retrieved from https://dx.doi.org/10.21512/comtech.v8i4.3885. doi:10.21512/comtech.v8i4.3885

Hair, J., Hult, G. T. M., Ringle, C., \& Sarstedt, M. (2014). A primer on partial least squares structural equation modeling (PLS-SEM). Thousand Oaks, CA: Sage Publications.

Hassani, H., Huang, X., \& Silva, E. (2018). Big-crypto: Big data, blockchain and cryptocurrency. Big Data and Cognitive Computing, 2(4). doi:10.3390/bdcc2040034

He, D., Habermeier, K. F., Leckow, R. B., Haksar, V., Almeida, Y., Kashima, M., . . Tiwari, S. (2016). Virtual currencies and beyond: Initial considerations. Staff Discussion Notes, 2016(003), A001. Retrieved from https://www.elibrary.imf.org/view/journals/006/2016/003/article-A001-en.xml. doi:10.5089/9781498363273.006.A001

Kahraman, D. (2019, Kasım). Kripto Varlık İşlem Platformu Düzenlemeleri, Türkiye Sermaye Birliği Piyasalar1. Gösterge, pp. 45-60. Retrieved from https://www.tspb.org.tr/wpcontent/uploads/2019/11/Gosterge_Guz_2019.pdf\#page=49

Karagöz, Y. (2016). SPSS 23 ve AMOS 23 Uygulamalı Istatistiksel Analizler. Ankara: Nobel Akademik.

Karaslan, H. F. (2018, 2 February). Ripple (XRP) Nedir? SteemKR. from https://steemkr.com/cointurk/@halilfatih/ripple-xrp-nedir-cointurk-11-projesi

K1lınç, Ş. (2017, 28 December). Ethereum Nedir, Bitcoin ile Arasındaki Farklar Nelerdir? Webtekno. Retrieved from https://www.webtekno.com/ethereum-ile-bitcoin-arasindaki-farklar$\underline{\mathrm{h} 38580 . \mathrm{html}}$

Kim, C. Y., \& Lee, K. (2018, 29-31 Jan. 2018). Risk Management to Cryptocurrency Exchange and Investors Guidelines to Prevent Potential Threats. Paper presented at the 2018 International Conference on Platform Technology and Service (PlatCon).

Kline, R. B. (2016). Principles and practice of structural equation modeling. New York: Guilford.

Koineks. (n.d.). Bitcoin Borsas1. Retrieved November 9, 2019, from https://koineks.com/

Koinim. (n.d.). Türkiye'nin kriptopara platformu. Retrieved November 9, 2019, from https://koinim.com/ 
Kraken. (n.d.). Bitcoin \& Cryptocurrency Exchange. Retrieved October 15, 2019, from https://www.kraken.com/en-us/

Krombholz, K., Judmayer, A., Gusenbauer, M., \& Weippl, E. (2017). The other side of the coin: User experiences with bitcoin security and privacy, Berlin, Heidelberg.

Kuisma, T., Laukkanen, T., \& Hiltunen, M. (2007). Mapping the reasons for resistance to Internet banking: A means-end approach. International Journal of Information Management, 27(2), 7585. Retrieved from https://www.sciencedirect.com/science/article/pii/S0268401206001149. doi:https://doi.org/10.1016/j.ijinfomgt.2006.08.006

Litecoin. (n.d.). Litecoin. Retrieved December 10, 2019 from https://litecoin.com/en/

Localbitcoins. (n.d.). Fastest and easiest way to buy and sell bitcoins. Retrieved October 15, 2019, from https://localbitcoins.com/

Lynn, T., Mooney, J. G., Rosati, P., \& Cummins, M. (2019). Disrupting finance : FinTech and strategy in the 21st century: Springer Nature.

Mendoza-Tello, J. C., Mora, H., Pujol-López, F. A., \& Lytras, M. D. (2018). Social commerce as a driver to enhance trust and intention to use cryptocurrencies for electronic payments. IEEE Access, 6, 50737-50751. doi:10.1109/ACCESS.2018.2869359

Nakamoto, S. (2008). Bitcoin: A Peer-to-Peer Electronic Cash System. Decentralized Business Review Retrieved from https://bitcoin.org/bitcoin.pdf

Narman, H. S., Uulu, A. D., \& Liu, J. (2018, 6-8 Dec. 2018). Profile Analysis for Cryptocurrency in Social Media. Paper presented at the 2018 IEEE International Symposium on Signal Processing and Information Technology (ISSPIT).

OKCoin. (n.d.). Leading Global Digital Asset Exchange. Retrieved November 10, 2019, from https://www.okcoin.com/

Oxford. (n.d.). Cryptocurrency. Available from Oxford Advanced Learner's Dictionary Retrieved 6 March, 2020 https://www.oed.com/view/Entry/79224404?redirectedFrom=cryptocurrency\#eid

Paribu. (n.d.). Türkiye'nin En Büyük Bitcoin Borsas1. Retrieved November 13, 2019, from https://www.paribu.com/\#/

Peters, G. W., Chapelle, A., \& Panayi, E. (2016). Opening discussion on banking sector risk exposures and vulnerabilities from Virtual currencies: An Operational Risk perspective. Journal of Banking Regulation, 17(4), 239-272. Retrieved from https://doi.org/10.1057/jbr.2015.10. doi:10.1057/jbr.2015.10

Rondan-Cataluña, F. J., Arenas-Gaitán, J., \& Ramírez-Correa, P. E. (2015). A comparison of the different versions of popular technology acceptance models. Kybernetes, 44(5), 788-805. Retrieved from https://doi.org/10.1108/K-09-2014-0184. doi:10.1108/K-09-2014-0184

Schueffel, P., Groeneweg, N., \& Baldegger, R. (2019). The Crypto Encyclopedia: Coins, Tokens and Digital Assets from A to Z. In. Bern, Switzerland: Growth publisher.

Shahzad, F., Xiu, G., Wang, J., \& Shahbaz, M. (2018). An empirical investigation on the adoption of cryptocurrencies among the people of mainland China. Technology in Society, 55, 33-40. Retrieved from https://www.sciencedirect.com/science/article/pii/S0160791X18300204. doi:https://doi.org/10.1016/j.techsoc.2018.05.006

Sobhanifard, Y., \& Sadatfarizani, S. (2019). Consumer-based modeling and ranking of the consumption factors of cryptocurrencies. Physica A: Statistical Mechanics and its Applications, 528, 121263. Retrieved from https://www.sciencedirect.com/science/article/pii/S0378437119307290. doi:https://doi.org/10.1016/j.physa.2019.121263 
Stergiou, D. (2019). EOS cryptocurrency initial coin offering: A case study. How the EOS cryptocurrency raised more than \$4.4 billion in its 2017 ICO. (Master Thesis), Blekinge Institute of Technology,

Szmigiera, M. (2020, February). Number of Blockchain wallets 2019 Statista. from https://www.statista.com/statistics/647374/worldwide-blockchain-wallet-users/

Tabachnick, B. G., Fidell, L. S., \& Ullman, J. B. (2007). Using multivariate statistics (Vol. 5): Pearson Boston, MA.

Tschorsch, F., \& Scheuermann, B. (2016). Bitcoin and beyond: A technical survey on decentralized digital currencies. IEEE Communications Surveys \& Tutorials, 18(3), 2084-2123. doi:10.1109/COMST.2016.2535718

Twentify. (2018, October). Türkiye'nin Sanal Cüzdan1. from https://www.twentify.com/tr/raporlar/turkiyenin-sanal-cuzdani-kripto-para-arastirmasi

Vebitcoin. (n.d.). Ripple-Algorand-Stellar Kripto Borsanız. Retrieved November 14, 2019, from https://www.vebitcoin.com/

Venkatesh, V., \& Davis, F. D. (2000). A theoretical extension of the technology acceptance model: Four longitudinal field studies. Management Science, 46(2), 186-204. Retrieved from https://pubsonline.informs.org/doi/abs/10.1287/mnsc.46.2.186.11926. doi:10.1287/mnsc.46.2.186.11926

Venkatesh, V., Morris, M. G., Davis, G. B., \& Davis, F. D. (2003). User acceptance of information technology: Toward a unified view. MIS Quarterly, 27(3), 425-478. Retrieved from http://www.jstor.org/stable/30036540. doi:10.2307/30036540

Verkijika, S. F. (2020). An affective response model for understanding the acceptance of mobile payment systems. Electronic Commerce Research and Applications, 39, 100905. Retrieved from $\quad$ https://www.sciencedirect.com/science/article/pii/S1567422319300821. doi:https://doi.org/10.1016/j.elerap.2019.100905

Walton, A., \& Johnston, K. (2018). Exploring perceptions of bitcoin adoption: The South African virtual community perspective. Interdisciplinary Journal of Information, Knowledge \& Management, 13, 165-182. Retrieved from https://search.ebscohost.com/login.aspx?direct=true\&db=asn\&AN=131448601\&lang=tr\&site $\equiv$ eds-live \&scope $=$ site $\&$ authtype $=$ ip,uid. doi:10.28945/4080

Weber, B. (2014). Bitcoin - the promise and limits of private innovation in monetary and payment systems. Monetary Policy \& The Economy(4), 53-66. Retrieved from https://EconPapers.repec.org/RePEc:onb:oenbmp:y:2014:i:4:b:3.

Westland, J. C. (2015). An introduction to structural equation models. In structural equation models: From paths to networks (pp. 1-8). Cham: Springer International Publishing.

WorldBank. (2018). Europe and Central Asia Economic Update, May 2018: Cryptocurrencies and Blockchain. Retrieved from https://elibrary.worldbank.org/doi/abs/10.1596/978-1-4648-12996 doi:10.1596/978-1-4648-1299-6

Yermack, D. (2015). Is Bitcoin a Real Currency? An Economic Appraisal. In Handbook of Digital Currency: Bitcoin, Innovation, Financial Instruments, and Big Data (pp. 31-43). Retrieved from https://www.sciencedirect.com/science/article/pii/B9780128021170000023?via\%3Dihub doi:10.1016/B978-0-12-802117-0.00002-3

Yilmaz, V., Can, Y., \& Aras, N. (2021). Kısmi en küçük kareler yapısal eşitlik modellemesiyle (PLSYEM) nükleer ve yenilenebilir enerjiye ilişkin tutumların araştırılması. Alphanumeric Journal, 7(1), 87-102. Retrieved from https://dergipark.org.tr/tr/pub/alphanumeric/issue/47067/460563. doi:https://dergipark.org.tr/tr/pub/alphanumeric/460563 


\section{APPENDIX}

Table 9. Questionnaire Items to Evaluate Usage Behaviour

\begin{tabular}{|c|c|c|c|c|}
\hline Item Code & Questionnaire Item & Mean & $\begin{array}{l}\text { Standard } \\
\text { Deviation }\end{array}$ & Variance \\
\hline $\mathrm{TF}_{1}$ & *Cryptocurrency enables to transfer money instantly. & 1.68 & 0.97 & 0.93 \\
\hline $\mathrm{TF}_{2}$ & $\begin{array}{l}* \text { Cryptocurrency enables to transfer money worldwide. } \\
* \text { Cryptocurrency enables to transfer money with low or no }\end{array}$ & 1.20 & 0.56 & 0.31 \\
\hline $\mathrm{TF}_{3}$ & transaction fees & 1.61 & 0.99 & 0.99 \\
\hline $\mathrm{SCF}_{1}$ & $\begin{array}{l}\text { *Using cryptocurrency is more secure than traditional money. } \\
\text { *Cryptocurrency empowers me with the control of my money. }\end{array}$ & 1.23 & 1.11 & 1.24 \\
\hline $\mathrm{SCF}_{2}$ & & 2.05 & 1.11 & 1.24 \\
\hline $\mathrm{DF}_{1}$ & $\begin{array}{l}\text { *With cryptocurrency I don't have to trust an authority. } \\
\text { *I use cryptocurrency because I disapprove the conventional }\end{array}$ & 1.82 & 1.07 & 1.15 \\
\hline $\mathrm{DF}_{2}$ & financial system. & 2.34 & 1.26 & 1.59 \\
\hline \multirow{4}{*}{$\mathrm{LRF}_{1}$} & $\begin{array}{l}* \text { Losses due to modifications to or vulnerabilities in the } \\
\text { protocols. }\end{array}$ & 2.16 & 1.08 & 1.17 \\
\hline & *Losses due to malfunction of the wallet providers. & 2.08 & 1.12 & 1.25 \\
\hline & $\begin{array}{l}\text { * Losses due to security incidents (e.g., lost passwords, } \\
\text { malware) }\end{array}$ & 1.70 & 1.01 & 1.01 \\
\hline & * Legal uncertainty for holders of cryptocurrency. & 1.73 & 0.95 & 0.90 \\
\hline $\mathrm{LRF}_{3}$ & $\begin{array}{l}\text { * Possible government intervention restricting the use of } \\
\text { cryptocurrency. }\end{array}$ & 2.13 & 1.15 & 1.32 \\
\hline \multirow[t]{2}{*}{$\mathrm{ARF}_{1}$} & *Lack of adoption in commerce in the long term. & 2.86 & 1.40 & 1.96 \\
\hline & $\begin{array}{l}* \text { Lack of interoperability with other digital service or } \\
\text { products. }\end{array}$ & 2.63 & 1.27 & 1.61 \\
\hline \multirow[t]{2}{*}{$\mathrm{PEU}_{1}$} & *Cryptocurrency is intuitive and easy to use. & 2.06 & 1.11 & 1.22 \\
\hline & $\begin{array}{l}\text { *Using cryptocurrency does not require a lot of mental or } \\
\text { learning effort. }\end{array}$ & 2.52 & 1.29 & 1.67 \\
\hline \multirow[t]{2}{*}{$\mathrm{UB}_{1}$} & *I prefer using cryptocurrency. & 1.51 & 0.80 & 0.65 \\
\hline & *I plan to continue using cryptocurrency. & 1.36 & 0.70 & 0.50 \\
\hline
\end{tabular}

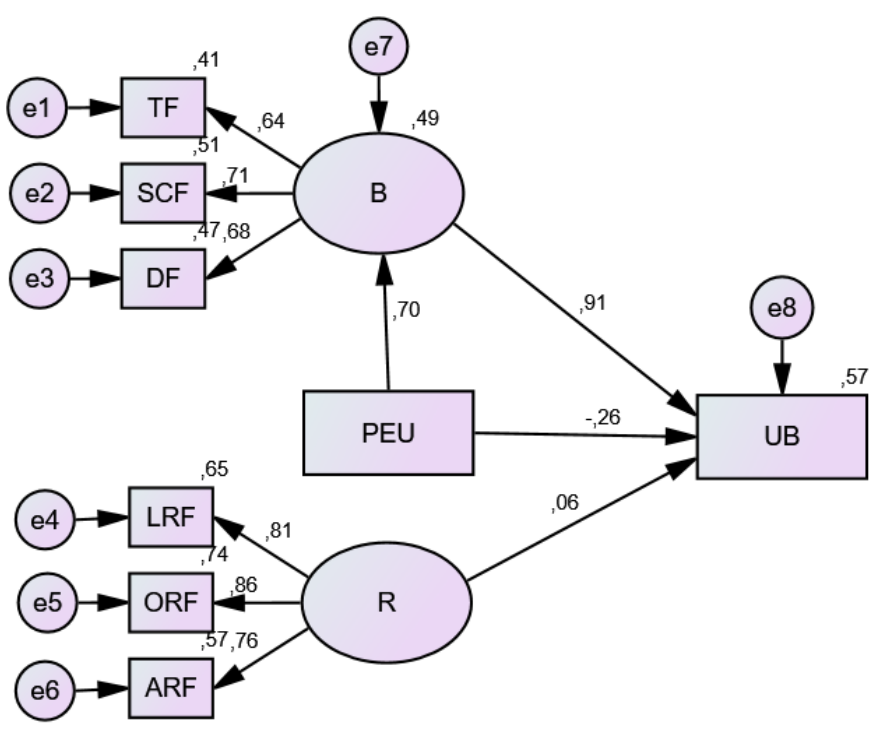

Figure 5. The Model's Screenshot in AMOS 24 